The Prime Minister of Antarctica: entrenching territory through journalistic travelogues

Jørgen Alnæs

Department of Media and Communication, University of Oslo

Postboks 1093 Blindern, 0317 OSLO, Norway

$+4748118212$

Jorgen.alnas@media.uio.no 


\title{
The Prime Minister of Antarctica: entrenching territory through journalistic travelogues
}

\author{
Abstract: \\ This article discusses how sovereignty can be entrenched through the interplay \\ between texts and actions. The case is the coverage of the Norwegian Prime Minister \\ Jens Stoltenberg's travels to Antarctica by one Norwegian newspaper, Aftenposten. \\ Through a close reading, the article shows how two newspaper articles by the \\ journalist Ole Mathismoen strengthen the connections between Norway and one of its \\ territorial claims in Antarctica while simultaneously obscuring other nations' presence. \\ Thus, the travelogues provide a setting for sovereignty performances by the Prime \\ Minister, which naturalises and depoliticises his actions. The article applies the \\ concept of imaginative geographies to illuminate relations between journalism and \\ geopolitics. By looking at the example of Norway's presence in Antarctica, it explores \\ how the performance of imaginative geographies functions as entrenchment of \\ territorial claims.
}

Key words: imaginative geographies; journalism; Antarctica; territory; symbolic entrenchment

\section{Introduction}

In January 2011, Norwegian Prime Minister Jens Stoltenberg started his traditional New Year's speech on television by paying homage to the explorer Roald Amundsen: "When Roald Amundsen planted the Norwegian flag on the South Pole, he placed Norway on the world map. A small nation showed the world that they could achieve much" (my translation) (Stoltenberg 2011a). He promised: "In December, I will participate in the celebration of the 100-year anniversary at the South Pole" (Stoltenberg 2011a).

Stoltenberg did as he promised: on 13 December 2011, a plane carrying the Prime Minister, his staff and a group of journalists arrived at the South Pole. Just hours later, the 
first articles describing the event were published. ${ }^{1}$ The journey to the South Pole was important in many respects. However, it is unlikely that the Prime Minister would have travelled to the South Pole if no one had been there to tell the story about it. The purpose of the travel was arguably the account of it.

An official voyage by a politician will always emphasise connections between the homeland and the visited area. Besides, some trips signal interests or obligations in foreign countries (e.g. the Emir of Qatar's visit to Gaza in 2012 or President Obama's visit to Afghanistan in 2014). Other travels may signal annexation of an area (e.g. Margaret Thatcher's visit to the Falkland Islands in 1982 or Vladimir Putin's visit to Crimea in 2014). To be realised as symbolic actions, such travels have to be narrated and communicated by journalists and photographers following the politician. Consequently, journalistic travelogues become a political tool. Journalistic texts can, of course, take a critical approach to such visits, but they can also present them as non-controversial. Furthermore, travelogues will accentuate existing imaginaries or create new ones. This depends on what the journalist observes and what the politicians say and do, but also on how the text is written: which style, words and figures are used to characterise the area, the journey and the politician. Through the journalistic texts, imaginary geographies (Said 1979, Bialasiewicz et al. 2007, Gregory 2004) are shaped and reproduced. Imaginative geographies are conventional ideas about an area's identity, its history, present and future, but the concept does also refer to the idea of the area as defined and knowable.

Antarctica provides a productive case for scrutinising the interplay between texts and actions in the process of shaping imaginative geographies. First, in that vast and uninhabited area, there are no meetings to attend and no local people to persuade - obviously the main reason for travelling there is to generate a story through which the politician can 
communicate. Second, although very few people have been to Antarctica, it is still well known: few other places on Earth are produced through mediation to the same degree (Glasberg 2012: xix). Third, Antarctica is a continent where sovereignty is contested and consequently an area where the performing of imaginative geographies may have geopolitical consequences. As Dodds and Nuttall (2015) state, "[t]he stories that we tell and listen to about these spaces and the way in which we engage with the Polar Regions have implications for their governance and for the geographical imaginaries that inform such governance" (88).

Sending high-profile political figures to Antarctica is not a specifically Norwegian practice. In the period 2013-15 the presidents of Chile and Peru, Australia's (then) former Prime Minister, New Zealand's Prime Minister and the King of Norway, among others, all visited Antarctica. According to the New Zealand government's webpage, Prime Minister John Key visited the continent “to highlight New Zealand's interests and activities in Antarctica and the Southern Ocean" (New Zealand Government 2013). Much the same reason was given by Jens Stoltenberg for his travel in 2008. When the latter travelled to Queen Maud Land, he told the Norwegian newspaper VG that he aimed to "stress possession" and emphasise that Norway has played and still plays an important role in Antarctica. He added that he wanted to examine the comprehensive climate research being conducted at Troll research station. ${ }^{2}$

Using examples from Norwegian news media coverage of the Prime Minister's journeys to Antarctica, I wll discuss how imaginative geographies are performed and how they are a part of the entrenchment of the Norwegian territorial claim in Antarctica. To do so, I shall focus on figures of clearing and constructing through which other people's history and interests are suppressed or erased and the Norwegian presence is emphasised. 
I shall look closely at two articles from the national newspaper Aftenposten about the Norwegian Prime Minister's journeys to Antarctica (in 2008 and 2011). Both texts are written by the well-known and well-respected climate journalist Ole Mathismoen. ${ }^{3}$ Thus, they represent a high-profile journalist's story about one high-profile politician. ${ }^{4}$ By limiting the analysis to two news articles, it is possible to conduct a close reading and identify emerging patterns.

The newspaper, Aftenposten, is one of the most central Norwegian news sources. It had the second largest circulation in Norway in 2008 and the largest in 2011 (MedieNorge). Politically it has been known as a conservative newspaper, but today it is found more in the centre.

\section{Governing Antarctica}

Antarctica is not just a huge, cold wasteland. The continent has natural resources and a strategic location, and many nations have interests there. Before the Second World War, Australia, New Zealand, Chile, Argentina, France, The United Kingdom and Norway claimed areas in Antarctica. These claims have never been acknowledged by other nations (Dodds 2012). In 1959, twelve nations, including the seven claim-holders, signed the Antarctic Treaty, which regulates and limits activity in the area. The treaty prohibits any military activity in Antarctica, but allows research and encourages scientific cooperation. Article IV is important. It states that nothing in the treaty shall be interpreted as a renunciation of previously asserted claims and that "[n]o acts or activities taking place while the present Treaty is in force shall constitute a basis for asserting, supporting or denying a claim to territorial sovereignty in Antarctica" (1951). Nevertheless, none of the claimant states have given up their claims. Alan Hemmings asserts that the idea of having claims in Antarctica is 
seldom debated: "The legacy of territorial sovereignty is never held up to the light within the political systems of the claimant states - neither whether it remains in principle as an acceptable form of contemporary state practice, nor in terms of the justice of the specific basis of claims of that state in the contemporary world" $(2012,72)$.

Since its creation, the treaty has been supplemented with related agreements about fishing, mineral exploitation and environmental protection, together called the Antarctic Treaty System. The claimant state's position within the Atarctic Treaty System has changed from majority to minority (Haward 2013). Originally twelve states has signed the treaty; seven claimant states and five more. By 201753 nations have signed the Treaty and there are 29 consultative parties. Thus, Antarctica and the surrounding ocean are often thought of as a global commons (Joyner 1998, Dodds 2012).

There are around 80 research stations in Antarctica, and some 5000 people stay there each summer (Dodds 2012). The United States and Russia are among the nations with the largest Antarctica budgets (Brady 2013), although neither has claims to Antarctica. According to Anne-Marie Brady (2013), activities and investments in Antarctica are used by nations with relatively strong economies (like China, India and the Republic of Korea) to assert international influence and build national pride. Research is also the ticket to being one of the consultative parties in the Antarctic Treaty System (Dodds 2012, 63). As Scott (2012) points out, science is also used by the claimant states to consolidate their claims, and all of them operate research stations within their respective areas and "fund more or less exclusively scientific research activities located therein" (Scott 2012, 284).

It is often said that the Antarctic Treaty "freezes" the sovereignty claims or that the claims are "frozen" as a consequence of the treaty. In Norway a similar expression, "lagt på is" (literary "placed on ice") is used by both journalists and the government. However, the 
accuracy of the metaphor is disputed. Klaus Dodds (2011) asserts that the Antarctic Treaty not only prepares for research and collaboration, but indirectly opens the way for different ways of executing power. Like Scott (2011), Dodds criticises the use of the word "frozen" because it gives the impression that the claims in Antarctica have not changed, but according to Dodds (2011), the claimant states have used what he calls "treaty sovereignty". In spite of the Antarctic Treaty, claimant states continue to champion their claims to domestic and international audiences, "whether it be via maps, postage stamps, public education, flag waving, place naming, scientific activity, the regulation of fishing, flying pregnant women to the region and public ceremonies such as commemoration" (Dodds 2011, 234). 
During the last several years Norway has made two claims to the sea area outside Queen Maud Land (Dronning Maud Land) and Bouvet Island (Bouvertøya). Also, in a white paper from 2015, the Norwegian government opened the door for new interpretations of the claimed territory's borders and thus a possible enlargement of the area (Utenriksdepartementet 2015). Furthermore, since 2005 the Norwegian government has increased its activity in Antarctica. ${ }^{5}$ Such activities has not drawn the attention of the Norwegian humanities scholars, even though different governmental engagements in Antarctica has been researched internationally, often framed as nationalism or “Antarctic nationalism" (Leane et al 2015, Hemmings et al 2015). Hemmings et al argue that such nationalism is a driving force in different states engagement in Antarctica, but in a different form than we usually see: "In the case of Antarctica, nationalism occurs instead in a 'virtual' and mediated form, remote from the territory of the peoples concerned and the states mobilised." (2015: 535). In a study of early polar expeditions Riffenburgh (1993) shows that nationalism has been central not only in the polar exploration itself, but also in the journalistic representation of it.

\section{Performing imaginative geographies}

The interconnections between texts and geopolitical actions can be illuminated through the concept of imaginative geographies. Imaginative geographies are conventional conceptions of a geographical area. Such conventions are not stable, and there can be different imaginative geographies referring to the same area. Imaginative geographies are crucial to understanding affiliation and sovereignty. Consequently, the shaping or reproduction of imaginative geographies can be an important political tool.

The concept of imaginative geographies was first developed by Edward Said in 1978. Said was concerned with the imaginaries of the area called "the Orient", which can serve as 
an example for how imaginative geographies work (Said 1994, 2000). His point is that "the Orient" is a social construction and a concept: "[A]s much as the West itself, the Orient is an idea that has a history and a tradition of thought, imagery, and vocabulary that have given it reality and presence in and for the West."(Said 1979: 5) Imaginative geographies are, of course, performative and produce the effects they name (Gregory 2004). Thus, they create political and spatial realities (Bialesievicz et al. 2007).

The concept of Antarctica can illuminate how imaginative geographies are produced. Long before the first people observed the continent, there were imaginaries about a huge continent in the south that was named Antarktikos and later Terra Antarctica (Leane 2012, 26). There were even theories about its natural resources (Leane 2012). Today, now that the area is measured and well mapped, it is not obvious what we should put in the category "Antarctica": which qualities characterize it; where should its borders be drawn; is it limited by the land, the ice-shelf or the sea-ice? It is also not certain how we should value it: is it a container for natural resources, or is it the last wilderness? Is it a global commons or the territory of the seven claimant states?

While Said's main concern was textual representations of "the Orient", geographers have since argued that practices can also produce imaginative geographies (Frank 2009, Watkins 2015). We have to consider, for example, that the erection of a memorial can be a result of imaginative geographies, but actions also shape emphasise and renegotiate the imaginative geographies. Soja's (1996) explanation is useful. He defines imaginative geographies as "dominating conventional representations of space as well as material spatial practices" (137).

The shaping and reproduction of imaginative geographies can be effective political tools for maintaining or emphasising sovereignty in unsettled areas. Hassner (2007) 
discusses the intractability of territorial disputes such as Gibraltar or the Golan Heights. He argues that such disputes become increasingly resistant to resolution over time because of different entrenching processes, such as mapping, building infrastructure and establishing administrative frameworks, but also because of symbolic entrenchment. Symbolic entrenchment is the production of historical, religious and ethnic connections between the homeland and the disputed territory: "These acts encourage a discourse that portrays the territory as unique to the homeland's identity and therefore without substitute" (Hassner $2007,117)$. The different entrenching processes are, of course, connected; disputes over economically valuable territory can evolve into ones over history and identity (Hassner: 113). As Dodds (2011) states, Hassner's term entrenchment is useful for describing how sovereignty is performed in Antarctica by the claimant states.

A text is not merely a neutral re-narrating of an event; it interprets, explains and contextualises the event, more or less explicitly. Thus, neither the imaginative geographies, nor the shaping of them are simply represented in journalistic texts. They are also performed in the media as a result of interplay between the politician and the journalist. In order to expose the performing of imaginative geographies I will scrutinise how the texts about the Prime Minister's travels are clearing the ground and constructing a Norwegian landscape.

\section{The first journey}

In January 2008 Jens Stoltenberg travelled to the Norwegian research station Troll in the claimed territory Queen Maud Land in Antarctica. Stoltenberg spent two days on the station, during which he was introduced to the scientific work done there, opened a satellite station and named a couple of mountains. Journalists from different Norwegian news media participated in the journey. 
On 20 January, Aftenposten published a two-page article with the title: "Ice-baptism when the boss arrived at the Norwegian dependency" [Is-dåp da sjefen kom til Norges biland] (All translations from the news articles are my own). The journalist, Ole Mathismoen, quotes Stoltenberg when he arrives at the base, follows him on a daytrip in the mountains and situates the trip in a historical and political context.

The title of the article refers to Stoltenberg's "baptism" of three mountains in the area, but it also signals the playful and less formal tone of the article. The first word, "Icebaptism", is a new construction typical of the journalistic news discourse. Similarly, referring to the Prime Minister as "the boss" is informal and part of what has been labelled colloquial discourse (Fairclough 1992) frequently found in Norwegian news articles. The use of the juridical term "dependency" instead of territory or area, however, is more surprising. Even though none of the three terms is unusual in news discourse, the combination of the informal and formal is uncommon and unexpected. The title can be read as clumsy, but it can also be taken as a conscious play on words,borrowing different forms of expression and combining them. Thus, in a pragmatic interpretation, the mix of discourse can be read as an intended, humorous move. A similar blend of discourses can be found in the rest of the article. This style makes the article more subjective, informal and entertaining; it signals that this is not heavy news or a controversial theme.

The topic of the reportage is the meeting between Stoltenberg and Antarctic nature. The article opens from the perspective of a little bird, the snow petrel.

The pure white snow petrel screams a warning as the Norwegian Prime Minister climbs up the stony mountainside. It doesn't give a damn about the boss's visit. The petrel is anxious about the nestlings that it is trying to bring 
up together with its mate in the short Antarctic summer. In a few weeks, it has to head for the coast and the Southern Ocean, where it stays for the winter. A south polar skua circles above us. It is hard to say who the petrel is most frightened of as it crosses rapidly back and forth above us - I find its mate later under a huge stone, guarding the nestlings - its common enemy up in the air, or Jens Stoltenberg with 30-40 researchers, civil servants and journalists in tow. (Aftenposten, January 20, 2008)

The snow petrel can be read as a pars pro toto for a vulnerable continent. This interpretation is supported by a short text, a column, on the left side of the reportage. The column has a byline photo at the top and is also signed by Ole Mathismoen in the bottom, which signal that this is opinion journalism. The column is about the untouched wilderness in Antarctica and the threat it faces from tourists and climate change. Thus, there is one voice visible in this double-page which is sceptical toward the Prime Minister's visit; he is the one who is disturbing the pristine natural environment. But this view is contrasted by the news article's enthusiastic description of the Prime Minister; he is presented as a rescuer, jumping out of the plane to defend a threatened continent.

In the last paragraph of the main piece we meet the snow petrel again, still screaming, even though it has nothing to fear (except the polar skua). As the Prime Minister is leaving, having finished the job, the sun appearsshows up, and the article ends on an optimistic note:

The snow petrels scream again as Jens [sic] jumps down the mountainside after the baptism of Trollvekjan. Simultaneously, the sun comes up again over the world's biggest ice massif. 
Under the airstrip are seven hundred metres of blue ice, thousands of years old. There is enough ice to raise the sea level by about 60 metres if it all melted. But that is, fortunately, almost inconceivable. (Aftenposten, January 20, 2008)

The article's layout is complex. The two pages contain a map of Antarctica and a sizeable photograph of Stoltenberg descending from an aircraft into a snowy landscape. He is wearing an outdoor outfit and solid boots, but he is bareheaded and looks relaxed and happy. The article appears in a recurring section of the paper with articles about global warming under the heading "Hot planet" [Het klode]. The name and picture of the journalist strengthens this framing: in 2008, Ole Mathismoen was well known and well respeced as a climate journalist. Thus, the paratexts connect the events in Antarctica to climate change. Although the article's title and the paratexts signal two different themes - climate change and the Prime Minister's emphasising of the Norwegian presence in Antarctica - the two themes are not framed as diverging or in conflict; as the playful title signals, this is a noncontroversial event. The two themes are merged seamlessly in the article. Still, from a geopolitical point of view, what is going on is a sovereignty performance. But the political implications of the event and the text are obscured because the event is partly framed as a story about the fight against climate change. Nevertheless, questions of sovereignty are explicitly discussed in the article. I shall return to this later.

\section{Clearing Antarctica}

Most Norwegian texts about Antarctica are about Norwegian expeditions and Norwegian research. The 2008 Aftenposten article is no exception; in addition to being about the Prime Minister's visit, it is about Norwegian polar research, Norwegian industry and Norwegian 
sovereignty. It is hardly surprising that a national newspaper has a national perspective; what is striking is the lack of presence of other nations. Queen Maud Land is big, almost seven times as big as Norway (Norwegian Polar Institute b), but not as empty as the text implies: South Africa, Germany, India, Russia and Japan have year-round research stations there, and Sweden and Belgium seasonal stations, all of which are connected by the Dronning Maud Land Air Network (DROMLAN). Yet none of these other bases is mentioned in the article, and the area appears untouched and empty. This matches the general picture that the article draws of Antarctica.

In the column, the journalist describes the feeling of standing somewhere that "maybe no one has stood [in] before" and being surrounded by "absolutely untouched nature". A similar fascination for pristine nature can be found in Norwegian travel and mountain literature, but by praising the untouched, virgin land, the journalist also draws on the discourse of polar exploration. In her analysis of early polar explorer discourses, Lisa Bloom (1993) has pointed out how expeditions to the polar regions "literalized the colonial fantasy of a tabula rasa where people, history and culture vanished" (Bloom 1993, 2).

The untouched nature of the Antarctic continent is also a theme in the main article. The journalist points out that before the Prime Minister's visit, the three baptised mountains have "for maybe 500 million years pointed at the sky without a name". When the lack of a name is seen as a noteworthy quality, the mountains are almost anthropomorphised; a name is seen as a part of a mountain's nature. But the lack of names also implies that this is wilderness where few people travel and few nations have interests. Furthermore, by mentioning the age of the mountains and inscribing their baptism in a 500 million year history, the journalist stresses the importance of the event. This is emphasised by the headline: the Prime Minister's actions are presented as a new beginning. 
The article goes on to inscribe Norwegians in the landscape. In the middle of the text, there is a paragraph about people who "have been keen to do things for the first time" in Antarctica: Roald Amundsen was the first person to reach the South Pole; Jens Stoltenberg was the first Norwegian Prime Minister to travel to Antarctica; Børge Brende was the first Norwegian minister in Antarctica and Sonja the first queen. Several non-Norwegian people have achieved remarkable firsts in Antarctica, but because the examples are presented as "a lot of people who..." and not as "a lot of Norwegians who ..." the implication is that the pioneers in Antarctica are usually Norwegians. This time it is not only Queen Maud Land but the whole continent that appears to be dominated by Norway and Norwegians.

This kind of rhetorical omission also occurs in the map that accompanies the article. The map contains six place names: "East-Antarctica”, "West-Antarctica”, "Dronning Maud Land" (Queen Maud Land), "Trollbasen" (Troll research station), "Scott-Amundsen-basen" (Amundsen-Scott South Pole Station) and "Fridtjof Nansen-fjellet" (Fridtjof Nansen Mountain). As the article references Norwegian sovereignty claims, it makes sense that the claimed area is marked on the map in addition to the Troll research station where the reportage took place. Furthermore, it is easy to see the arguments for including the bestknown research station, the Amundsen-Scott South Pole Station. Even though the name is incorrectly written ("Scott Amundsen [...]") and even if it also calls attention to the British polar explorer, the station-name remind us of the Norwegian history and presence on the continent. More peculiarly, the map includes a mountain called "Fridtjof Nansen-fjellet". The mountain was first observed by Roald Amundsen's expedition in 1911 and then given the name "Fridtjof Nansens fjeld"(Norwegian Polar Institute a). It is located outside the Norwegian claim, but the name "Mount Fridtjof Nansen" is accepted by New Zealand, the United States and Russia (Norwegian Polar Institute a). However, this is not an important, 
famous, or remarkable mountain, and it is not included in the official Norwegian Antarctica map (Norwegian Polar Institute, 2013). By identifying only this mountain, the map in Aftenposten elevatesthe presence of the famous Norwegian explorer and diplomat in the landscape. Furthermore, the map gives the impression that Antarctica is a continent in which few other nations have interests or traditions.

Texts that refer to a concrete area can legitimise appropriation by describing the area as uninhabited, uncultivated, virgin or unknown. Spurr (1993) identifies a rhetorical mode "by which Western writing conceives of the Other as absence, emptiness, nothingness or death" (92). Such negation is closely connected to colonisation and, according to Spurr, "acts as a kind of provisional erasure, clearing a space for the expansion of the colonial imagination and for the pursuit of desire" (92-93). Ashcroft (2005) labels the same process "erasure" and uses examples of how pre-colonised areas are called virginal or characterised by their "un-ness" and "not-ness" (97). He also connects the figure of erasure to the colonising process: "Colonial ground needs to be erased, wiped clean, to prepare it for imperialism's darkest gift - the gift of newness" (Ashcroft, 2005: 93). In this article I shall use the term clearing. While erasure and negation imply that something is removed, I want to stress the point that by simply stepping around or by not emphasising other people's history, presence or interests, a space can be cleared and made ready for appropriation.

Because Aftenposten's news article omits the presence, interests and history of other nations, the continent appears empty. Consequently, Norwegian land-claiming and the performance of sovereignty seems less problematic. But as the examples above show, the negation or clearing of Antarctica is hardly isolated from the emphasis placed on the Norwegian presence. When one thing is made present another thing is not mentioned. 


\section{Constructing Norwegian territory}

As mentioned by Dodds (2012), the act of naming areas may be a form of symbolic entrenchment. Early in the text the baptism is described. The mountains were assigned typical Norwegian mountain-names; Trollguten, Trolltinden, Trollveikja (wrongly spelt Vekja in Aftenposten). The names chosen are a part of the entrenchment. They imply that those mountains share traits with the mountains in Norway, and that they are more closely connected to Norway than to other Antarctic mountains.

By emphasising the act of naming the mountains, and by featuring the baptiser Jens Stoltenberg, the article connects the area to an event and consequently gives it a history and a meaning. Ashcroft (2005) points out narration's role in the colonising process:

"the names given to such space invoke the connotations of the culture from which they emerged. But it is narration that confirms the place as place. By narration, space is located in time" (Ashcroft 2005: 103).

By means of personification, landscape is given a human character: the nameless mountains are baptised as newly born children, two of them even given names which associate the mountains with young humans: Trollguten means the troll boy, Trollveikja means the troll girl. The anthropomorphised landscape meets the Norwegian head of government. This way of narrating the baptism makes it clear that area is included as part of the nation.

The article repeatedly reaffirms the perception that the area belongs to Norway. The title tells us that this is a Norwegian dependency, the body of the text refers to Stoltenberg 
as "the boss" and provides an explicit explanation of the sovereignty question. But why dwell on this if the area is rightfully and indisputably Norwegian?

In the middle of the article there is an explicit clarification of the sovereignty issue:

\footnotetext{
And yesterday, the Norwegian dependency Dronning Maud Land was captured by the Kingdom's Prime Minister for the first time. True, this is not a formal part of the kingdom itself, it is a so-called dependency. And the Norwegian sovereignty claim was literally frozen when Norway signed the Antarctic Treaty in 1958. But both the [Norwegian] Criminal Code and other basic laws are in force here. [emphasis in original]
}

The Prime Minister does not arrive or visit; he "captures" the dependency. ${ }^{6}$ This renders the journey more important and formal, but it also makes him more powerful. However, the word "capture" together with "Kingdom" is part of a slightly ironic style. Norwegian newspapers seldom refer to Norway as "The Kingdom". As mentioned, the article is a personal reportage with touch of humour, and the journalist here seems to play with a more ceremonial and pompous style when discussing juridical questions. Who is the target of the humour? It is, in fact, not the Prime Minister, who is presented as sympathetic, enthusiastic and responsible. The text even states that "formalities and grandeur are not what usually characterise him". It is possible instead to read the pompous phrases as ridiculing the legal system in Antarctica. The article's style implies that formalities are not important. It may also work as a rhetorical buffer, distancing the journalist from a geopolitical struggle over the continent.

In the quotation above it is reasonable to read "the Kingdom" as a reference to both Norway and Queen Maud Land. The implication is that Queen Maud Land is a part of the 
Norwegian Kingdom. The next sentence denies the implied assertion, but with numerous reservations: "True, this is not a formal part of the kingdom itself, it is a so-called dependency" (emphasis added). Through these reservations, the author implies that he does not share the view that "this is not Norwegian territory".

By obscuring the performance of sovereignty, the journalist simultaneously asserts his integrity. If the sovereignty question is clarified, if the travel is not primarily a way to entrench Norwegian territory, the journalist is less vulnerable to charges of being a tool of the government. This move can also be seen as an example of what Pratt (1992) calls anticonquest. In her study of travel literature she uses the term to describe how "European bourgeois subjects seek to secure their innocence in the same moment as they assert European hegemony" (Pratt, 1992: 7). Pratt describes anti-conquest as taking a position against earlier forms of imperial travel writing. In Aftenposten it is a way to secure both the journalist's and the Prime Minister's innocence and to underline their good intentions.

\section{The second journey}

In 2011, Stoltenberg visited Antarctica again. This time he travelled to the South Pole to celebrate the Norwegian explorer Roald Amundsen, who had reached the pole 100 years earlier. The celebration consisted of a ceremony that included speeches from Stoltenberg and others. Stoltenberg also unveiled a bust of Amundsen made of ice.

This time on his trip to the South Pole, the Prime Minister was accompanied by a few members of his staff and only a few journalists, including Ole Mathismoen from Aftenposten. Following an agreement with the Prime Minister's office, one of Mathismoen's articles was distributed to several national and regional newspapers. The article was titled "Ice-cold Amundsen unveiled on the South Pole" (Aftenposten, December 15, 2011) and 
covered the main event: the anniversary ceremony and the unveiling of the bust. The article was also published online on the Aftenposten website. In the online version, the unveiling of the bust is a main theme; it is emphasised in the title, in the picture and in the introduction. Unusually for a Norwegian online news article, there is a byline picture; there is also a short video of Stoltenberg skiing at the South Pole.

There are several similarities between the articles from 2008 and 2011: both focus on one person, Jens Stoltenberg, both retell old stories about Norwegian heroes and both are written in an occasionally informal and humorous style. There is, however, an important difference between the two destinations and between the two areas described. While the Troll Station is located approximately in the middle of the territory claimed by Norway, the South Pole is the point where all the sovereignty claims meet. Besides, the northern and southern borders of the Norwegian claim are undefined. On some official Norwegian maps, the territory is marked from the coast to the pole, in other maps the claim is limited by a curved line around 85 degrees south. ${ }^{7}$ Thus the South Pole appears to be a more contested territory than Queen Maud Land. This makes the travelogues interesting: both the travel to the South Pole and the unveiling of the bust can be seen as political actions; but, since the travels and actions take place on a more complicated political ground, politicians and journalists alike are expected to be more careful in their establishing of the Norwegian presence.

Even if the pole is on the margin of the Norwegian territorial claim, it has a specific role for Norwegians. Amundsen's conquest of the South Pole is widely known and celebrated; for Norwegian history, the South Pole is arguably the most important place outside Norway. The Pole and the story about its conquest has been referred to in textbooks, stamps, monuments, different clothing brands and of course in biographies and 
explorer literature. A premise in the Norwegian narrative about Amundsen is that the conquest of the pole has been enduringly important. It "placed Norway on the world map" as Stoltenberg formulated it. This presupposes not only that the South Pole is connected to Norway, but also that Norway is connected to the South Pole: if the conquest of a geographical point is that important, the conquerors will arguably be connected to it forever.

The Antarctic Treaty allows contracting parties to establish bases in Antarctica, and the United States has had a year-round research station at the South Pole since 1956. Even though the base is American, it is named the Amundsen-Scott South Pole Station in honour of Roald Amundsen and the British explorer Robert Scott. The two polar pioneers are also honoured side by side on a sign marking the geographic pole nearby the station.

The double honouring of the explorers from Norway and Great Britain is an important statement. It implies that the area does not belong to one single nation, either legally or historically. As a diplomatic move it gives the United States the possibility to position itself between the two claimant states at Antarctica's geographic and symbolic centre. Thus the United States, and not Norway or Great Britain, appears as the symbolic superpower in Antarctica.

In this perspective, the installation of the ice bust of Amundsen in 2011 can be interpreted as an attempt to reconquer the South Pole. A durable memorial honouring only Amundsen signals that there is still only one conqueror of the pole. The uniqueness of Amundsen's achievement is a fundamental part of Norwegian identity, and for Norwegian readers it is a matter of course that he should be honoured alone at the South Pole. 


\section{Clearing the South Pole}

While Mathismoen's other articles from the South Pole narrate the life and ongoing research at the Amundsen-Scott South Pole Station, the base and its staff are almost absent from this article. Observant readers will, however, discern the presence of others in the text. In one formulation, the article reveals that other people inhabit the pole; they are denoted as "residents". The base is mentioned when the Norwegian Prime Minister donates a Norwegian flag to it. In the video and in a small photo at the bottom of the article it is possible to observe some buildings in the background. Simon Stephenson from the United States' Antarctic program is quoted, but the text does not say whether he arrived with the Prime Minister or is stationed at the Pole. The small picture shows a crowd gathered around the bust, and the caption states: "It is rarely this crowded at the pole [...]". The American presence at the pole is thus almost wiped out. By diminishing other nations' presence and history at the South Pole, the article makes the Norwegian memorial more salient.

By using Amundsen's name to signify the bust and the personifying adjective ice-cold, the title suggests a humorous interpretation of the unveiling. ${ }^{8}$ Together with the photo, the title emphasises the material in the bust and implies that the choice of ice as material is clever and funny. This emphasis on humour makes the event seem less controversial. Thus, the humour functions in the same way as in the 2008 article; namely, it obscures the political dimension of the event. The bust's unusual material is also a theme in the article. Early in the text Mathismoen writes:

The United States' Antarctic Program did not want a new permanent memorial at the South Pole - consequently it was an accurate ice-copy of sculptor Håkon Martin Fagerås' 
Amundsen bust that was unveiled yesterday. The Prime Minister's staff, with help from the South Pole's 'residents', worked intensely for several days to create the bust. Presumably it will last for a while; ice melts down slowly here. (Aftenposten, December 15, 2011)

Interestingly, Mathismoen avoids saying anything about the initiative to install the bust. "Did not want" is an understated way of saying the Americans did not want, refused or opposed the idea of a durable memorial. ${ }^{9}$ But it also obscures the question about the initiative for installing one. In the same way, the lack of an agent in the formulation "consequently it was an accurate ice copy [...] that was unveiled" masks the fact that erecting the bust is a Norwegian project. The Norwegians become visible only when it comes to the production of the bust, but here they are cooperating with the Americans at the base.

The text does not try to hide the presence of the Americans at the South Pole butthey appear as visitors to a place that is, as we shall see, portrayed as Norwegian.

\section{Constructing a Norwegian Pole}

As discussed earlier, erasing the presence of others can seldom be separated from emphasising one's own presence. The picture of the bust and the title "Ice-cold Amundsen unveiled on the South Pole 100 years later" focus on the bust itself more than the ceremony at the Pole. The apostrophic speech by the head of the Norwegian Polar Institute, JanGunnar Winther, quoted in the first part of the article, makes the person Amundsen even more present: "You went into totally unknown terrain". But the events could also have been presented in other ways. Stoltenberg's speech at the South Pole concentrates on Amundsen, but more than half of it is about polar research and climate change (Stoltenberg 2011b). 
Some non-Norwegian newspapers also covered the events at the pole. The Daily Mail announced "'One of the greatest feats in human history': Norway's PM hails Amundsen's Antarctic journey on $100^{\text {th }}$ anniversary of reaching the South Pole ${ }^{10}$ and the Telegraph: " $100^{\text {th }}$ anniversary of Roald Amundsen reaching South Pole is honoured" ${ }^{11}$ In contrast to Aftenposten, they focused on the achievement rather than the person. It is not surprising that a Norwegian newspaper would focus on Norwegians. Still, this national perspective seems to tie in with Aftenposten's other ways of connecting the pole to Norway.

When the Norwegian Prime Minister travelled to the South Pole to celebrate Amundsen, the news story about it not surprisingly concentrated on two events: Amundsen's expedition and Stoltenberg's honouring of it. Nevertheless, the article draws a line from the past to the present in a noteworthy way: the introduction points out that it is exactly 100 years since Amundsen reached the pole. The first sentence in the body text repeats the point "exactly 100 years later" and underlines the proximity between the two events: "it was extremely cold that time - and it was extremely cold tonight". But there are more than physical connections between Amundsen and contemporary Norwegians. In the second quotation from Stoltenberg he states that “Roald Amundsen's polar expeditions contributed to the shaping of Norway's new national identity". The implication is that, like Amundsen, Norway is capable of great achievements.

By quoting Simon Stephenson's appreciation of Amundsen's preparation, teamwork and passion, the journalist implies that Norwegians are not the only ones who are inspired by Amundsen. But even if people from other nations are inspired, the connection between Amundsen's expedition and modern Norwegians appears distinctive. The last paragraph in the article reports that Stoltenberg went skiing earlier the same day, following Amundsen's 
route to the pole. This is also the theme of the short video included in Aftenposten's online version of the article.

The introduction of the article situates the event as an anniversary at the pole 100 years after Amundsen "planted the Norwegian flag there". These are the same words Stoltenberg uses to describe Amundsen's feat in his New Year speech quoted above. This expression emphasises the fact that it was a Norwegian expedition. Alternative formulations like "since the pole was reached", "since the conquest of the pole" or, as Simon Stephenson put it, "since the discovery of the last great continent started" would not have marked the achievement itself as lesser, but would have made less visible that this was a Norwegian expedition. Additionally the formulation "planted the Norwegian flag" brings forth the sovereignty question. When he arrived at the South Pole, Roald Amundsen did plant a flag so this phrase could be interpreted as nothing more than a reference to historical facts. But to raise a flagpole with the flag of one's country in an apparent no-man's-land is regarded as a form of appropriation. And Roald Amundsen did in fact claim the land at the South Pole plateau; he even named it "Haakon VII's vidde" after the Norwegian king at the time. Thus, to write that he planted the flag at the South Pole is also a reference to the land claim. Still there is not necessarily a relation between a flag-planting and a land claim. Today flags are raised in camps all over the world, even at mountains and poles, even though no areas are actually being claimed. One might say that in the formulation "planted the flag" there is an unsettled relation between the concrete flag planting and the abstract land claim; it is unclear if the formulation is a synecdoche for appropriation, a reference to the fact that a flag was raised - or something in between. The ambiguity makes it possible for the text to draw attention to the fact that Amundsen was first, and that such achievements traditionally have accorded some privileges, without taking a stand. 
To erect and unveil a bust is a way to define and determine the meaning of a place in the same way as place-naming and mountain-naming. In the same way as in 2008 , the account of the travel was the way the Prime Minister's actions became known; thus the news story is also a part of the place-making. However, there are different ways to report such events. This time, as in 2008 , the reporter follows the protagonist in more than one sense. The article contributes to the shaping of an idea about the South Pole as a place unique to Norway, and Norway as strongly connected to the South Pole.

\section{The struggle over geography}

The close reading of the two newspaper articles reveals how conceptions of Antarctica are performed through several details in two journalistic texts. T. Through the simultaneous and mutually dependent figures of clearing and constructing, Norway's presence in Antarctica is naturalised. Norway is portrayed as an important and significant actor and the connections between it and Antarctica are strengthened. Consequently the imaginative geographies of Antarctica in the text function as entrenchment of the territory claimed by Norway.

I argue that the imaginative geographies of Antarctica are performed through an interplay between actions and texts. This interplay is not simply a cooperation between a journalist and his sources in which the actions and utterances of the latter are communicated by the former. The events that Mathismoen wrote about in 2008 and 2011 would most likely never have happened were they not going to be covered. Conversely, without the events, there would have been no text . Of course, the texts could have provided a different another backdrop for the actions. This can be illustrated by the coverage of the first journey. The newspaper VG's more critical article, "Struggling about the world's ice-cold big brother" (January 26, 2008), focuses on natural resources in Antarctica 
and different states' interests in the continent. Still, such framings of the events contributes to the strengthening of the Norwegian claim, though to a lesser extent: the article in VG presents the government's actions to strengthen Norway's connection to Antarctica, but in a way that opens up for questioning and critique. Consequently, the form of the textual representation is crucial in the performing of Norwegian territory. In Aftenposten's narration of events, they were presented as uncontroversial and almost non-political: other nations' history and interests were concealed and Norwegian presence emphasised through the figures of clearing and constructing. Thus, this case shows how news media, by arranging political/symbolic actions in a particular context, can contribute to a naturalising of those actions. The political actions will appear as an uncontroversial, a-political and likely way of relating to the actual area. This way, the news texts presuppose the imaginative geographies which the political actions attempt to shape or reproduce.

Stuart Elden (2013) stresses that territory has to be regarded as more than simply an area: "Territory is itself a process, made and remade, shaped and shaping, active and reactive" (17). As Doreen Massey (1994) has stated, space has to be understood as a result of interrelations, and thus as dynamic and changing. Edward Said (1994) makes a similar point, stating that

"Just as none of us is outside or beyond geography, none of us is completely free from the struggle over geography. That struggle is complex and interesting because it is not only about soldiers and cannons but also about ideas, about forms, about images and imaginings" (7). 
This is an important point. Geography is continuously renegotiated. Consequently, every text that refers to or discusses an area or narrates its history is both a product and a performance of imaginative geographies. If the conceptions of space, territory and geography are processual, changing and constantly renegotiated, the depiction or labelling of an area cannot be easily separated from the governing of it. Thus, the picture that a news article draws of an area will always be political.

\section{Literature}

Ashcroft, Bill. 2005. "Forcing Newness into the World: Language, Place and Nature." ARIEL: A Review of International English Literature 36: 1-2.

Bialasiewicz, Luiza, David Campbell, Stuart Elden, Stephen Graham, Alex Jeffrey, and Alison J Williams. 2007. "Performing security: The imaginative geographies of current US strategy." Political Geography 26 (4): 405-422.

Bloom, Lisa. 1993. Gender on Ice. American Ideologies of Polar Expeditions. Minneapolis: University of Minnesota Press.

Brady, Anne-Marie. 2013. The emerging politics of Antarctica. London: Routledge.

Dodds, Klaus. 2011. "Sovereignty watch: claimant states, resources, and territory in contemporary Antarctica." Polar Record 47 (3): 231-243.

Dodds, Klaus. 2012. The Antarctic: A Very Short Introduction. Oxford: Oxford University Press.

Dodds, Klaus, and Mark Nuttall. 2015. The Scramble for the Poles. The Geopolitics of the Arctic and Antarctic. Cambridge: Polity Press.

Elden, Stuart. 2013. The Birth of Territory. Chicago: The University of Chicago Press.

Fairclough, Norman. 1992. Discourse and social change. Cambridge: Polity Press.

Frank, Michael C. "Imaginative geography as a travelling concept. Foucault, Said and the Spatial turn." European Journal of English Studies 13 (1): 61-77.

Glasberg, Elena. 2012. Antarctica as Cultural Critique. The Gendered Politics of Scientific Exploration and Climate Change. New York: Palgrave Macmillan.

Gregory, Derek. 2004. The Colonilal Present. Malden: Blackwell.

Hemmings, Alan D. 2012. "Security beyond claims." In Antarctic Security in the Twenty-First Century, edited by Alan D.Hemmings, Donald R. Rothwell, and Karen N. Scott, 70-94 London: Routledge.

Hemmings, Allan D., Sanjay Chaturverdi, Elizabeth Leane, Daniella Liggett and Juan Francisco Salazar. 2015. "Nationalism in Today's Antarctic." The Yearbook of Polar Law VII: 531-555.

Joyner, Christopher C. 1998. Governing the frozen commons: the Antarctic regime and environmental protection. Columbia, S.C.: University of South Carolina Press.

Leane, Elizabeth 2012. Antarctica in Fiction. Imaginative Narratives of the Far South. New York: Cambridge University Press.

Leane, Elizabeth, Tim Winter and Juan Francisco Salazar. 2015. "Cauth between nationalism and internationalism: replicating histories of Antarctica in Hobart." 2016. International Journal of Heritage Studies 22 (3): 215-227

Massey, Doreen. 1994. A global sense of place. Minneapolis: University of Minnesota Press.

Mathismoen, Ole. (2007) 2008. Klima. Kva skjer? Oslo: Font forlag 
MedieNorge: data retrriewed from MedieNorge's database http://medienorge.uib.no/ 02.12.2017

New Zealand Government (2013). "Prime Minister to visit Antarctica"

https://www.beehive.govt.nz/release/prime-minister-visit-antarctica. Access date 7.7.2016

Norwegian Polar Institute (2013). Antarctica [map]. 1: 10000 000. Troms $\varnothing$

Norwegian Polar Institute a "Stadnamn i norske polarområde." [Database] URL: http://placenames.npolar.no/stadnamn. Access date June 262016.

Norwegian Polar Institute b "Dronning Maud Land" URL:

http://www.npolar.no/no/antarktis/dronning-maud-land.html Access date: Descember 2 2017

Pratt, Mary Louise. 1992. Imperial Eyes: Travel writing and Transculturation. London: Routledge.

Rognhaug, Magnus Hovind (ed.). 2014. Norway in the Antarctic. Troms $\varnothing$ : Norwegian Polar Institute.

Said, Edward W. 1979. Orientalism. New York: Vintage Books.

Said, Edward W. 1994. Culture and Imperialsm. New York: Vintage Books.

Said, Edward W. 2000. "Invention, memory, and place." Critical inquiry 26 (2): 175-192.

Scott, Karen N.. 2012. "Scientific rhetoric and Antarctic security." In Antarctic Security in the TwentyFirst Century, edited byby Alan D. Hemmings, Donald R. Rothwell, and Karen N. Scott . London: Routledge.

Scott, Shirley V. 2011. "Ingenious and innocuous? Article IV of the Antarctic Treaty as imperialism." The Polar Journal 1 (1): 51-62.

Soja, Edward W. 1996. Thirdspace. Journeys to Los Angeles and Other Real-and-Imagined Places. Malden: Blackwell Publishing.

Spurr, David. 1993. The rhetoric of empire: colonial discourse in journalism, travel writing and imperial administration. Durham, N.C.: Duke University Press.

Stoltenberg, Jens. 2011a. "Statsministerens nyttårstale 2011." [Speech] retrieved from https://www.regjeringen.no/no/aktuelt/statsministerens-nyttarstale-2011/id629901/ Descember 42017

Stoltenberg, Jens. 2011b. "Tale ved 100-årsmarkeringen av Amundsen-ekspedisjonen til Sydpolen." [Speech] URL: https://www.regjeringen.no/no/dokumentarkiv/stoltenbergii/smk/lyd-og-bilde/2011/tale-ved-100-arsmarkeringen-av-amundsen-/id668079/ Access date: Descember 42017

Treaty, The Antarctic. 1959. Washington, D. C. .

Utenriksdepartementet. 2015. Norske interesser og politikk i Antarktis. Meld. St. 32 (2014-2015), [White paper] URL: https://www.stortinget.no/no/Saker-ogpublikasjoner/Saker/Sak/?p=61854 Access date Descember 32017

Watkins, Josh. 2015. "Spatial Imaginaries Research in Geography: Synergies, Tensions, and New Directions." Geography Compass 9 (9): 508-522.

\footnotetext{
1 "Jens har landet", VG nett, January 19, 2008 URL: http://www.vg.no/nyheter/innenriks/jens-harlandet/a/515518/ Access date: June 14, 2016.

2 "Jens har landet", VG nett, January 19, 2008 URL: http://www.vg.no/nyheter/innenriks/jens-harlandet/a/515518/ Access date: June 14, 2016.

${ }^{3}$ The year before, Mathismoen published a book about climate change: Klima. Hva skjer? (2007).

${ }^{4}$ In addition, the selected news articles formed a significant part of the coverage of the Prime Minister's travel; through different agreements both articles were distributed to, and published by, several Norwegian newspapers.

${ }^{5}$ As far as governmental spending or number of research stations is concerned, Norway is a small nation in Antarctica (Brady, 2013). Nevertheless, the Norwegian government have established an airfield and built a satellite station at the Troll research station in Queen Maud Land. Norway is ranked number 1 in krill-fishing in Antarctica, and up to $20 \%$ of the Antarctic tourism has been channeled through Norwegian operators (Rognhaug 2014).
} 


\footnotetext{
${ }^{6}$ In Norwegian: «inntok».

${ }^{7}$ See for example Doods and Nuttall (2015) and Dodds (2012).

${ }^{8}$ In Norwegian, the adjective "iskald" (here translated to "ice-cold") can connote a rational and cold personality, but it can also be a reference to temperature.

${ }^{9}$ In Norwegian "har ikke ønsket".

10 "'One of the greatest feats in human history': Norway's PM hails Amundsen's Antarctic journey on 100th anniversary of reaching the South Pole" Daily Mail, December 14, 2011. URL:

http://www.dailymail.co.uk/news/article-2073997/Norways-PM-hails-Roald-Amundsen-100th-anniversaryreaching-South-Pole.html\#ixzz4DibQAzQQ Access date: October 13, 2015.

11 "100th anniversary of Roald Amundsen reaching South Pole is honoured" The Telegraph, December 14, 2011. URL: http://www.telegraph.co.uk/news/worldnews/antarctica/8956091/100th-anniversary-of-RoaldAmundsen-reaching-South-Pole-is-honoured.html_Access date: October 13, 2015.
} 